\title{
PELATIHAN PEMBUATAN SIRUP BUAH NIPAH SEBAGAI PRODUK UNGGULAN DESA SEMPAN KABUPATEN BANGKA
}

\author{
Nurhadini $^{1)}$, Verry Andre Fabiani ${ }^{1)}$, Ristika Oktavia Asriza ${ }^{1)}$, Fajar Indah Puspita \\ Sari $^{1)}$ \\ 1) Jurusan Kimia, Fakultas Teknik, Universitas Bangka Belitung \\ e-mail: nurhadini88@gmail.com
}

\begin{abstract}
Sempan Village is one of the villages in Pemali District of Bangka Regency, Bangka Belitung Islands which do not yet have the featured products, while this village has nipah plants that not used optimally. The nipah fruit can be processed into a featured product of village i.e. syrup. The service program Chemistry Department is training Sempan Village society on the manufacture of syrup from nipah fruit. The method of this activity includes three stages i.e. preparation, implementation and evaluation. After this activity is carried out, the Sempan Village society have increased understanding, knowledge and motivation in utilising nipah fruit into processed syrup products and this product is expected become one of the featured products of Sempan Village.
\end{abstract}

Keywords: nipah fruit, syrup, Sempan Village

\begin{abstract}
Abstrak
Desa Sempan merupakan salah satu desa di Kecamatan Pemali Kabupaten Bangka, Kepualuan Bangka Belitung yang belum memiliki produk unggulan sedangkan desa ini memiliki tanaman nipah yang kurang dimanfaatkan secara optimal. Buah nipah dapat diolah lebih lanjut menjadi produk unggulan desa yaitu sirup. Program pengabdian berupa pelatihan kepada masyarakat Desa Sempan mengenai pembuatan sirup dari buah nipah. Metode pelaksanaan kegiatan ini meliputi tiga tahapan yaitu persiapan, pelaksananaan dan evaluasi. Setelah kegiatan ini dilaksanakan masyarakat Desa Sempan memiliki peningkatan pemahaman, pengetahuan dan motivasi dalam memanfaatkan buah nipah menjadi produk sirup dan produk ini diharapkan dijadikan salah satu produk unggulan Desa Sempan.
\end{abstract}

Kata Kunci: buah nipah, sirup, Desa Sempan 


\section{PENDAHULUAN}

Desa Sempan merupakan salah satu dari enam desa yang berada di Kecamatan Pemali, Kabupaten Bangka. Desa Sempan memiliki luas wilayah $34,25 \mathrm{~km}^{2}$. Secara umum, desa yang berada di Kecamatan Pemali memiliki berbagai sektor ekonomi unggulan seperti tanaman pangan, perikanan, perkebunan, peternakan, kehutanan, perdagangan, industri dan pertambangan (BPS, 2018). Berdasarkan informasi dari Kepala Desa Sempan bahwa terdapat beberapa buah dari Desa Sempan salah satunya yaitu buah nipah yang saat ini pemanfaatannya belum optimal. Selain itu belum adanya produk unggulan desa.

Tanaman nipah banyak dijumpai disekitar daerah pesisir dan pantai. Buah nipah tua mengandung sekitar $17,5 \%$ protein; $0,7 \%$ lemak dan $56 \%$ serat (Khalil dan Hidayat, 2006). Buah nipah dapat diolah lebih lanjut menjadi tepung dan pakan ternak. (Heriyanto dkk, 2011; Khalil dan Hidayat, 2006). Selain itu buah nipah dapat dimanfaatkan sebagai sirup yang meningkatkan nilai jual dan daya simpan buah. Sirup ini dapat dijadikan produk yang menambah pendapatan desa dan masyarakat setempat.

Berdasarkan kondisi di Desa Sempan tersebut maka permasalahan yang yang ada di Desa Sempan yaitu belum adanya produk unggulan Desa Sempan, kurang optimalnya pengolahan buah nipah dan tingkat pengetahuan warga tentang pengolahan buah nipah masih rendah. Oleh karena itu program pengbdian ini dibuat berupa pelatihan pembuatan sirup olahan buah nipah sebagai produk unggulan Desa Sempan. Program pengabdian ini mengundang masyarakat di Desa Sempan terutama ibu-ibu PKK dan pemuda- pemudi karang taruna. Program ini diharapkan dapat menjadi alternatif dalam pengembangan produk unggulan desa.

\section{METODE}

Program Pengabdian Masyarakat Jurusan Kimia Universitas Bangka Belitung Tahun 2019 dilaksanakan di Desa Sempan Kabupaten Bangka. Peserta ini berasal dari masyarakat desa Sempan (ibu-ibu PKK dan karang taruna, perangkat desa), mahasiswa dan dosen Jurusan Kimia Universitas Bangka Belitung (UBB). Metode pelaksanaan kegiatan ini meliputi tiga tahapan yaitu persiapan, pelaksananaan dan evaluasi.

\section{Persiapan}

Persiapan terdiri atas penentuan lokasi kegiatan, survey dan izin kegiatan, dan persiapan alat dan bahan.

2. Pelaksanaan

Tahap pelaksanaan terdiri atas pemberian materi dan praktik langsung. Pemberian materi ke masyarakat bertujuan untuk peningkatan wawasan dan pengetahuan masyarakat mengenai manfaat dan pembuatan sirup dari buah nipah. Praktik dilakukan melalui demontrasi tiap pembuatan sirup nipah.

\section{Evaluasi}

Tahap evaluasi dilakukan dengan pemberian angket untuk mengetahui tingkat pemahaman dan pengetahuan masyarakat terhadap pembuatan sirup buah nipah.

\section{HASIL DAN PEMBAHASAN}

Program Pengabdian Masyarakat Jurusan Kimia UBB di Desa Sempan, Kabupaten Bangka dilaksanakan pada tanggal 1 Agustus 2019 bertempat di Aula Desa Sempan. Kegiatan ini dihadiri sekitar 50 peserta yang terdiri dari warga desa, perwakilan ibu-ibu PKK, Karang Taruna, perangkat desa dan dosen serta mahasiswa Jurusan Kimia Universitas Bangka Belitung. Kegiatan ini dibuka oleh Perangkat Desa Sempan yang diwakili oleh Sekretaris Desa Sempan, kemudian dilanjutkan dengan 
penyampaian materi dan demontrasi pembuatan sirup buah nipah.

\section{Sosialisasi Pembuatan Sirup Olahan Buah Nipah}

Pembuatan sirup buah nipah disampaikan ke masyarakat Desa Sempan dengan metode diskusi dan praktik. Kegiatan ini diawali dengan sosialisasi dengan menyampaikan materi mengenai buah nipah dan cara pengolahannya menjadi sirup.

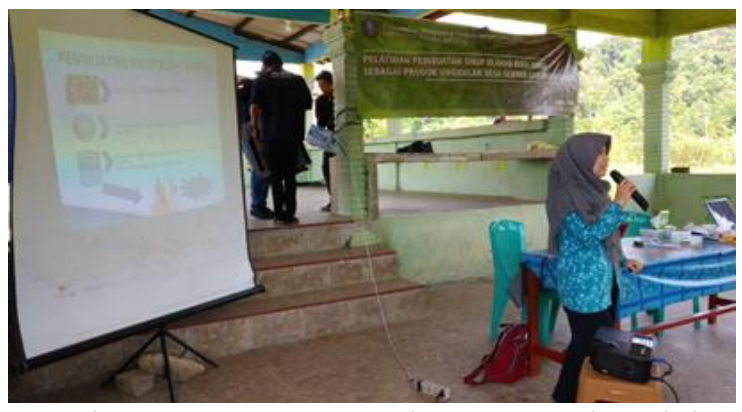

Gambar 1. Penyampaian Materi Oleh Tim Pengabdian Masyarakat Jurusan Kimia UBB Tahun 2019

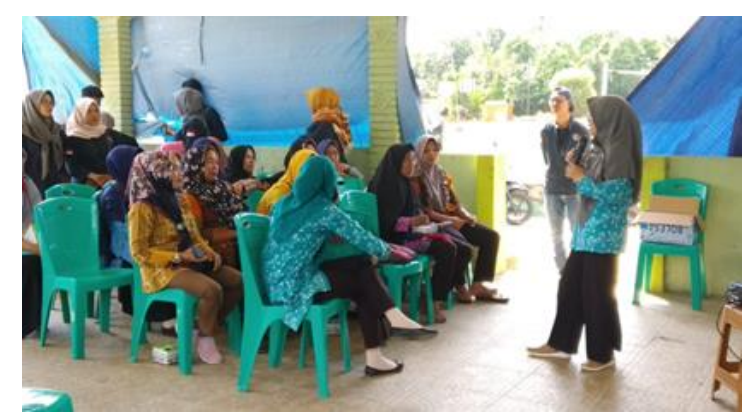

Gambar 2. Diskusi Dengan Masyarakat Sempan

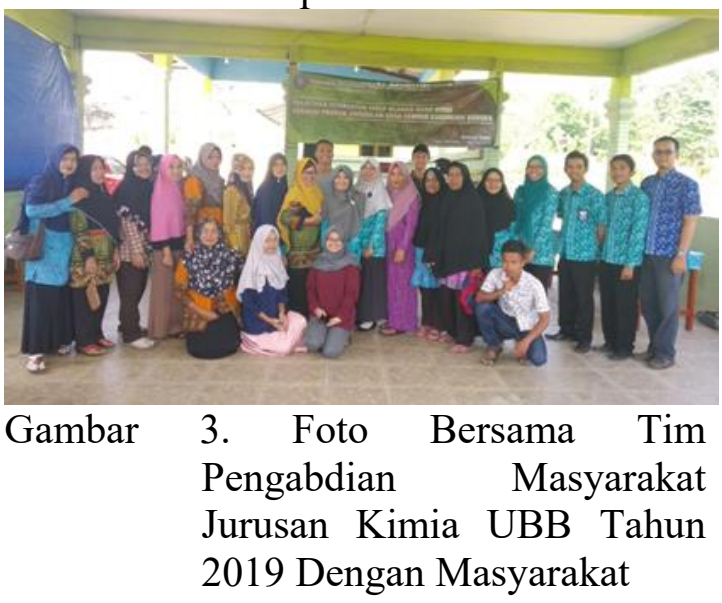

Kegiatan sosialisasi ini diikuti oleh masyarakat dengan antusias yang diindikasikan dengan adanya tanya jawab atau diskusi mengenai materi yang telah disampaikan dan pengembangan produk unggulan Desa Sempan yang dapat dikembangkan berbasis buah nipah.

Perangkat Desa terutama masyarakat Desa Sempan sangat berterima kasih karena melalui program ini desa Sempan memiliki alternatif dalam mengembangkan produk yang ingin dikembangkan menjadi produk unggulan Desa Sempan dan memotivasi masyarakat dalam memanfaatkan buah nipah untuk diolah menjadi produk unggulan desa

\section{Praktik Pembuatan Sirup Buah Nipah}

Kegiatan selanjutnya adalah praktik pembuatan sirup buah nipah bersama masyarakat desa Sempan. Masyarakat diikutsertakan secara langsung dengan berpartisipasi dalam pembuatan sirup nipah. Kegiatan ini diawali dengan mengumpulkan bahan yang diperlukan yang telah disiapkan sebelumnya bersama masyarakat dan tim Pengabdian Masyarakat Jurusan Kimia UBB. Praktik ini menggunakan bahan utama yaitu buah nipah yang sudah dikupas dan gula yang selanjutnya diolah sesuai dengan materi kegiatan sosialisasi yang telah disampaikan sebelumnya.

Sirup buah nipah hasil olahan ini berwarna putih dan tidak berbau khas seperti kebanyakan sirup buah sehingga lebih mudah dimodifikasi lebih lanjut. Selain itu pengolahan sirup buah nipah menghasilkan produk samping berupa ampas buah nipah yang masih dapat diolah menjadi tepung atau pangan lainnya. Buah nipah memiliki kandungan karbohidrat, protein, gula dan vitamin $\mathrm{C}$ sehingga berpotensi dikembangkan berbagai produk selain sirup (Subiandono, dkk., 2011). 
Nama Penulis 1, dkk.Pengolahan Limbah Plastik Menjadi Produk...

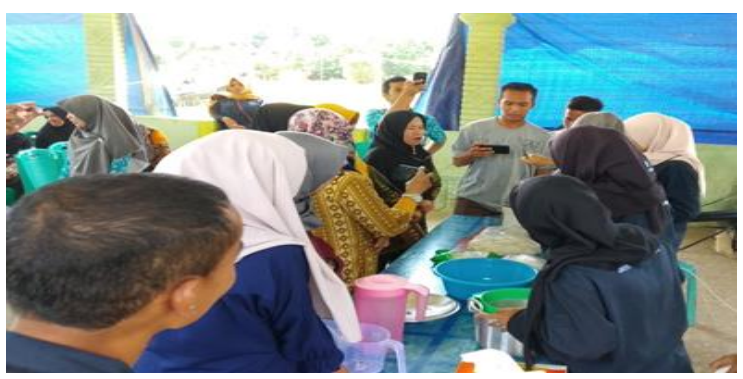

Gambar 4. Praktik Pembuatan Sirup Buah Nipah

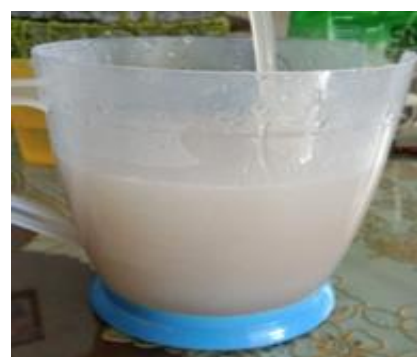

Gambar 5. Sirup Buah Nipah

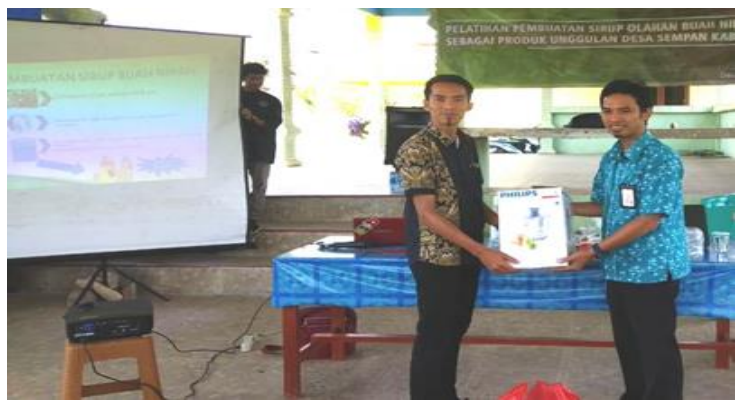

Gambar 6. Serah Terima Peralatan Sirup Buah Nipah Ke Perangkat Desa Sempan

\section{Evaluasi Program}

Tahap evaluasi ini dilakukan dengan pemberian angket ke masyarakat mengenai program yang telah dilaksanakan. Pada evaluasi ini dapat diketahui tingkat pemahaman dan pengetahuan masyarakat setelah mengikuti program ini.

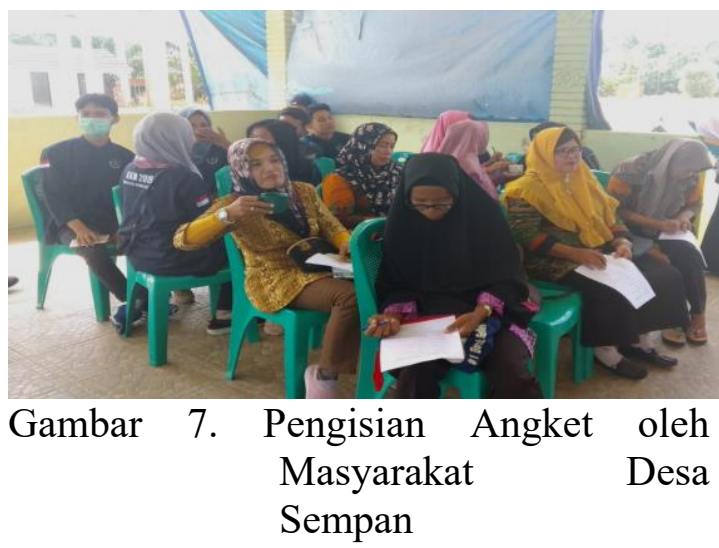

Proses pengisian angket dilakukan sebanyak dua kali untuk mengetahui tingkat pemahaman dan pengetahuan mengenai kegiatan ini. Tabel 1 berisi daftar beberapa pertanyaan pada kuisioner.

Berdasarkan Tabel 1 diketahui bahwa masyarakat Desa Sempan mendapatkan peningkatan pengetahuan dan keterampilan dalam mengolah buah nipah menjadi sirup. Pelatihan ini juga memberikan pengetahuan baru dalam membuat produk berbasis buah nipah yang berpotensi dikembangkan menjadi produk unggulan Desa Sempan.

Tabel 1. Hasil Kuisioner Program Pengabdian Jurusan Kimia UBB

\begin{tabular}{|c|l|c|c|c|c|}
\hline \multirow{2}{*}{ No } & \multicolumn{1}{|c|}{ Pertanyaan } & \multicolumn{2}{|c|}{ Pretest } & \multicolumn{2}{c|}{ Post Test } \\
\cline { 3 - 5 } & & Ya & Tidak & Ya & Tidak \\
\hline 1 & Apakah anda familiar dengan buah nipah & $100 \%$ & $0 \%$ & & \\
\hline 2 & Apakah anda mengetahui manfaat buah nipah & $20 \%$ & $80 \%$ & $100 \%$ & $0 \%$ \\
\hline 3 & $\begin{array}{l}\text { Apakah anda mengetahui buah nipah dapat dibuat } \\
\text { sirup }\end{array}$ & $0 \%$ & $100 \%$ & $100 \%$ & $0 \%$ \\
\hline 4 & $\begin{array}{l}\text { Apakah anda mengetahui cara pembuatan sirup } \\
\text { buah nipah }\end{array}$ & $0 \%$ & $100 \%$ & $100 \%$ & $0 \%$ \\
\hline 5 & $\begin{array}{l}\text { Apakah pelatihan ini meningkatkan kemampuan } \\
\text { saudara dalam mengolah buah nipah }\end{array}$ & & $100 \%$ & $0 \%$ \\
\hline 6 & $\begin{array}{l}\text { Apakah pelatihan ini berpotensi meningkatkan } \\
\text { ekonomi desa }\end{array}$ & & $100 \%$ & $0 \%$ \\
\hline 7 & $\begin{array}{l}\text { Apakah buah nipah dapat dijadikan produk } \\
\text { unggulan desa }\end{array}$ & & $100 \%$ & $0 \%$ \\
\hline
\end{tabular}




\section{SIMPULAN}

Kegiatan Pengabdian Masyarakat Jurusan Kimia Tahun 2019 meningkatkan pemahaman, pengetahuan dan memotivasi masyarakat di Desa Sempan dalam memanfaatkan buah nipah menjadi produk olahan berupa sirup. Produk ini diharapkan dijadikan salah satu produk unggulan Desa Sempan. Program ini diharapkan dapat dikembangkan lebih lanjut hingga Desa Sempan memiliki produk unggulan berbasis buah nipah.

\section{UCAPAN TERIMA KASIH}

Penulis mengucapkan terima kasih kepada Universitas Bangka Belitung yang telah mendanai pelaksanaan kegiatan pengabdian ini.

\section{DAFTAR PUSTAKA}

Badan Pusat Statistik Kabupaten Bangka, 2018. Kecamatan Pemali Dalam
Angka, Badan Pusat Statistik Kabupaten Bangka, ISBN : 978602-0123-70-9.

Heriyanto, N.M., Subiandono, E., dan Karlina, E. 2011, Potensi Dan Sebaran Nipah (Nypa fruticans (Thunb.) Wurmb) Sebagai Sumberdaya Pangan (Potency and Distribution of nypa palm (Nypa fruticans (Thunb.) Wurmb) as Food Resource)). Jurnal Penelitian Hutan Dan Konversi Alam, Vol. 8, Hal. 327-335

Khalil dan Hidayat, T. 2006, Potensi Buah Nipah Tua (Nypa Fruticans Wurmb) Sebagai Bahan Pakan Ternak. Jurnal Peternakan Indonesia, Vol. 11, Hal. 123-128.

Subandiono, E., Heriyanto, N.M., dan Karlina, M. 2011. Potensi Nipah (Nypa fruticans (Thumb.)Wurmb.) Sebagai Sumber Pangan dari Hutan Mangrove, Buletin Plasma Nutfah, Vol 17, Hal. 54-60 